\title{
Periodic fever in everyday paediatric practice - case report of 6-year-old girl and a literature review
}

\author{
Gorączka nawrotowa w codziennej praktyce pediatrycznej - prezentacja przypadku \\ 6-letniej dziewczynki z przeglądem piśmiennictwa
}

\author{
'Student's Paediatric Scientific Association at the Department of Paediatric, Preventive Cardiology and Immunology of Developmental Age, Medical University of Lodz, tódź, Poland \\ ${ }^{2}$ Department of Paediatric, Immunology and Nephrology, Polish Mother's Memorial Hospital Research Institute in Lodz, Łódź, Poland \\ ${ }^{3}$ Division of Didactics in Paediatrics, Medical University of Lodz, tódź, Poland \\ Correspondence: Małgorzata Stańczyk, MD, PhD, Department of Paediatric, Immunology and Nephrology, Polish Mother's Memorial Hospital Research Institute in Lodz, Rzgowska 281/289, 93-338 Łódź, Poland, \\ tel.: +4842271 13 94, fax: +48 42 271 13 90, e-mail: mbstanczyk@gmail.com
}

Abstract PFAPA syndrome (periodic fever, aphthous stomatitis, pharyngitis, cervical adenopathy) is the most common periodic fever syndrome occurring in children. Exacerbation period is characterised by episodes of high fever with pharyngitis, cervical lymphadenopathy and increased inflammatory markers. It is believed that the PFAPA syndrome does not increase sepsis markers. In the paper, we present a clinical case of a 6-year-old girl who was presented with recurrent fever episodes. After exclusion of other causes, PFAPA syndrome was diagnosed. Recurrences of fever were accompanied by an elevated level of procalcitonin and C-reactive protein. Corticosteroid treatment caused a permanent remission of the disease symptoms. Discussion is focused on increased inflammatory markers and the differentiation of the syndrome with generalised bacterial processes. Widening the knowledge of the syndrome among general practitioners and paediatrics is crucial for early diagnosis and implementation of proper treatment.

Keywords: fever, autoinflammation, procalcitonin, children

Zespół PFAPA (periodic fever, aphthous stomatitis, pharyngitis, cervical adenopathy) to najczęstsza gorączka nawrotowa, występująca głównie u dzieci. W okresie zaostrzeń charakteryzuje się cyklicznie pojawiającymi się epizodami wysokiej gorączki z towarzyszącym zapaleniem gardła, aftami błony śluzowej jamy ustnej oraz powiększeniem węzłów chłonnych szyi. Objawom klinicznym często towarzyszą podwyższone wartości markerów zapalnych, przy czym uważa się, że w zespole nie dochodzi do podwyższenia stężenia wskaźników posocznicy. W pracy omówiony został przypadek 6-letniej dziewczynki diagnozowanej z powodu nawracających epizodów gorączki, u której po wykluczeniu innych przyczyn ustalono rozpoznanie PFAPA. Nawrotom gorączki towarzyszyły podwyższone surowicze stężenia białka C-reaktywnego oraz prokalcytoniny. W wyniku zastosowanego leczenia glikokortykosteroidami uzyskano trwałą remisję objawów. W omówieniu zwrócono szczególną uwagę na wysokość wskaźników stanu zapalnego i odróżnianie zespołu PFAPA od uogólnionych procesów bakteryjnych. Poszerzenie wiedzy na temat możliwego przebiegu schorzenia wśród lekarzy podstawowej opieki zdrowotnej oraz wśród pediatrów umożliwi wcześniejsze rozpoczęcie diagnostyki różnicowej oraz szybsze wdrożenie prawidłowego leczenia.

Słowa kluczowe: gorączka, autozapalenie, prokalcytonina, dzieci 


\section{INTRODUCTION}

C ases of children with periodic fever of unknown origin pose many diagnostic and therapeutic difficulties in everyday paediatric practice. Dissemination of knowledge on the possible course of periodic fever syndromes could improve diagnosis and care in these patients ${ }^{(1)}$. PFAPA (periodic fever, aphthous stomatitis, pharyngitis, cervical adenopathy), a relatively new clinical entity first described by George Marshall in 1987, is the most common periodic fever syndrome. It was then given the acronym FAPA (fever, aphthous stomatitis and cervical adenitis). Two years later, the name was changed to PFAPA in order to emphasise the periodic nature of fever, which is the main and the most characteristic symptom of the disease ${ }^{(2)}$. PFAPA is classified in the group of autoinflammatory diseases characterised by periodic fever, which may be accompanied by a variety of symptoms in most body systems ${ }^{(3)}$. PFAPA symptoms are often correlated with increased inflammatory markers ${ }^{(4)}$. The prevalence of the syndrome is not known as it is often underdiagnosed ${ }^{(1)}$. Therefore, general practitioners and paediatricians should consider whether to pay greater attention to patients with recurrent pharyngitis and cyclic febrile episodes in the absence of other symptoms, as well as whether the accompanying increased inflammatory markers are always an indication for antibiotic therapy.

\section{CASE REPORT}

An almost 6-year-old girl was admitted to the Department due to fever of up to $40^{\circ} \mathrm{C}$ accompanied by the symptoms of pharyngitis and palatine tonsillitis as well as submandibular lymphadenopathy. Medical history revealed that the child experienced similar episodes once a month for about 3 days (regardless of treatment used) since the age

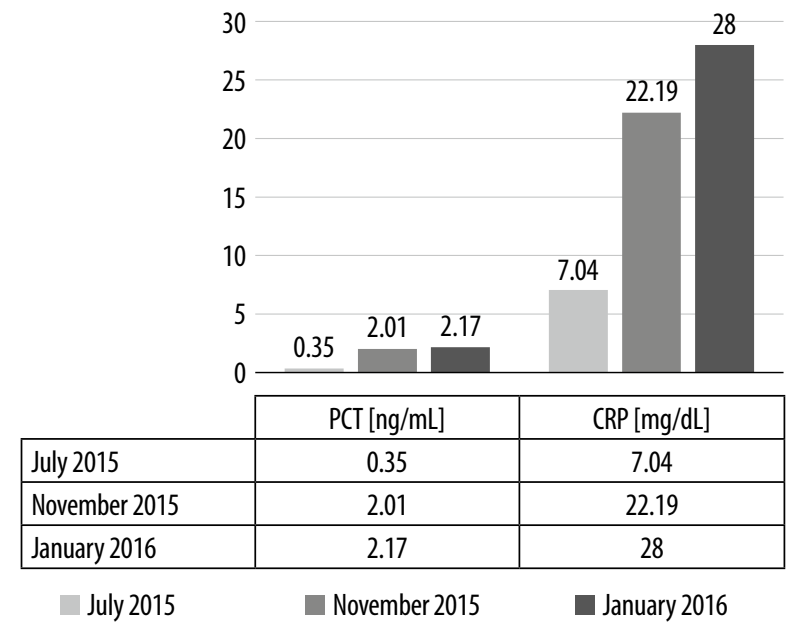

Fig. 1. Procalcitonin $(P C T)[n g / m L]$ (normal: $<0.05)$ and C-reactive protein $(C R P)[\mathrm{mg} / \mathrm{dL}]$ levels $($ normal: $<1.0)$ during subsequent hospital stays of 3 years. Between the febrile periods, the child's condition was good. The febrile periods were accompanied by increased inflammatory markers, which normalised during afebrile intervals. Due to the presented symptoms, the girl repeatedly received antibacterial therapy with cotrimoxazole, ceftriaxone, amikacin, clindamycin, clarithromycin, and ceftazidime. During her four hospital stays, the child developed fever of $39-40^{\circ} \mathrm{C}$, accompanied by pharyngitis and palatine tonsillitis with white-coated tonsils as well as lymphadenopathy. Laboratory findings showed high leukocytosis, increased C-reactive protein (CRP) and procalcitonin (PCT) (Fig. 1).

Extensive diagnosis pointed to possible Borrelia burgdorferi infection (IgG Western blot positive for Borrelia), Yersinia infection, and rheumatoid disease (positive cyclic citrullinated peptide antibodies and rheumatoid factor). Other causes of symptoms were excluded (Tab. 1).

Bone marrow puncture was performed to exclude neoplastic process as the cause of periodic fever - myelographic findings did not deviate significantly from normal. During the last hospital stay, the child's general condition was good, with abnormal findings including elevated body temperature, submandibular lymphadenopathy and enlarged, white-coated palatine tonsils. The girl negated pharyngeal pain. Laboratory tests showed significantly increased inflammatory markers (CRP $28 \mathrm{mg} / \mathrm{dL}$, normal <1.0; PCT $2.17 \mathrm{ng} / \mathrm{mL}$, normal $<0.05)$ and increased leukocytosis $\left(19.69 \times 10^{3} / \mu \mathrm{L}\right)$. Due to the justified suspicion of another periodic fever episode, prednisone was administered at a single dose $(1 \mathrm{mg} / \mathrm{kg})$ instead of antibiotic therapy, achieving permanent fever resolution already on day 1 of treatment. Laboratory follow-up one day after prednisone administration showed normal leukocytosis $\left(11.43 \times 10^{3} / \mu \mathrm{L}\right)$, CRP of $4.38 \mathrm{mg} / \mathrm{dL}$, and PCT of $0.74 \mathrm{ng} / \mathrm{mL}$. PFAPA was diagnosed based on good response to prednisone and other clinical manifestations. Further, several-month follow-up showed a decreasing tendency of febrile episodes. The symptoms resolved permanently at the age of 10 years. No tonsillectomy was performed.

\section{DISCUSSION}

The diagnosis of PFAPA is primarily based on a thorough clinical analysis, fulfilment of diagnostic criteria and exclusion of other causes of symptoms. The first step to a correct diagnosis is to pay attention to the recurrent nature of symptoms. A "fever diary" kept by parents to record data

\footnotetext{
- Parasitic diseases: toxoplasmosis, ascariasis, toxocariasis

- Viral diseases: cytomegalovirus disease, infectious mononucleosis

- Urinary tract infection

- Cyclic neutropenia

- Streptococcal infection and other specific bacterial infections

(i.e. yersiniosis, Lyme disease)

- Neoplastic process
}

Tab. 1. A list of exclusion criteria in the differential diagnosis in the presented case 


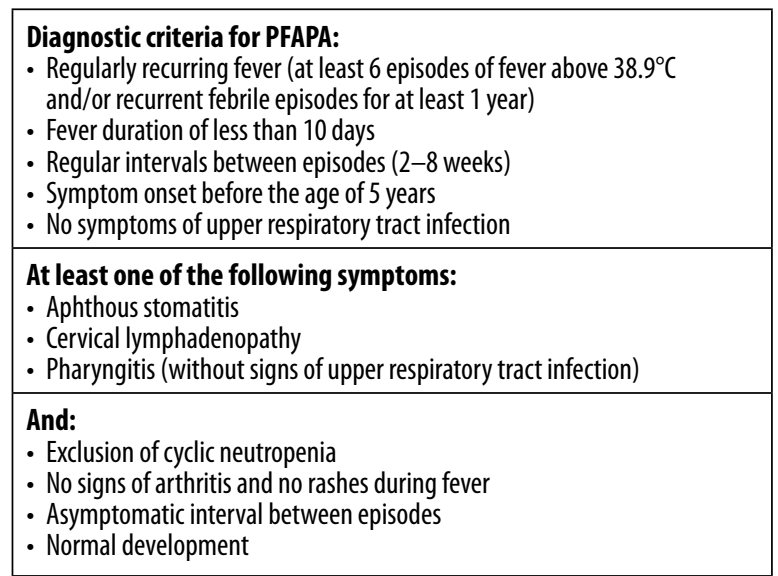

Tab. 2. Diagnostic criteria for PFAPA according to WolskaKuśnierz et al. ${ }^{(5)}$

on the dates of fever episodes and the associated symptoms may be helpful. Also, a thorough analysis of child's medical records will help verify earlier diagnoses. Patients with fever of unknown origin are usually diagnosed with a three-day fever, urinary tract infection, infectious mononucleosis, pneumonia, or Kawasaki disease, which are not always confirmed by the child's clinical condition or laboratory tests. The episodes of fever in PFAPA syndrome are typically accompanied by cervical lymphadenopathy and palatine tonsillitis with inflammatory exudate of varying morphology. Their appearance may suggest both viral and bacterial infection. Additionally, aphthous ulcers of various sizes may occur in the oral cavity. Laboratory tests performed during a fever relapse indicate generalised inflammation. Once the symptoms resolve, the patients usually present with no other manifestations. The child develops normally, and the increased inflammatory markers normalise ${ }^{(5)}$. There are currently no specific investigations or tests that would allow for a clear diagnosis. Therefore, thorough medical history and an assessment of the clinical condition are crucial. Diagnostic criteria for PFAPA are shown in Tab. 2.

It should be noted that the increase in CRP and PCT is not always indicative of an infectious aetiology of a disease. Although infections are the most common cause of increased inflammatory markers, their reference levels may

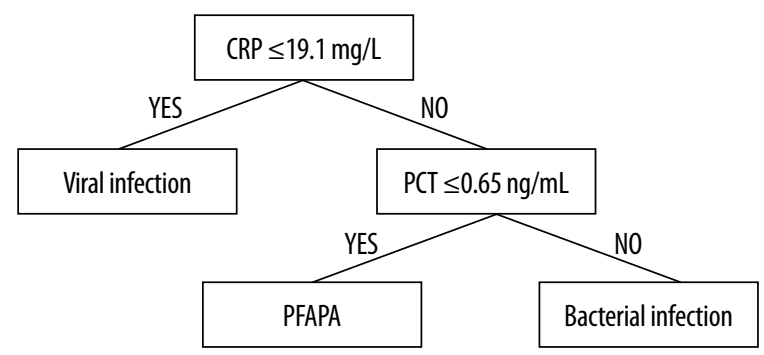

Fig. 2. A decision tree diagram model for the differentiation between PFAPA episodes and acute infections based on procalcitonin (PCT) and C-reactive protein (CRP) levels, proposed by Kraszewska-Głomba et al. ${ }^{(10)}$ be also exceeded in rheumatological diseases, other inflammatory conditions, malignancies, or a response to medications ${ }^{(6)}$. Yazgan et al. showed that the mean CRP levels during a febrile episode in children with PFAPA were $94.8 \pm 71.6 \mathrm{mg} / \mathrm{L}$ (normal: $0-10 \mathrm{mg} / \mathrm{L}$ ), and the mean PCT was $0.29 \pm 0.14 \mathrm{ng} / \mathrm{mL}$ (normal: $0-0.5 \mathrm{ng} / \mathrm{mL}$ ) ${ }^{(7)}$. These findings are in line with other studies confirming increased CRP during febrile episodes in patients with PFAPA $^{(8,9)}$. Kraszewska-Głomba et al. presented a decision tree diagram to differentiate between an infectious and an autoimmune aetiology based on inflammatory markers. According to these authors, low CRP levels are typical of viral infections. Most patients with PFAPA and bacterial infections have CRP levels $\geq 19.1 \mathrm{mg} / \mathrm{L}$ (normal levels up to $10 \mathrm{mg} / \mathrm{L}$ ). It was suggested that PCT may be the differentiating factor, with PCT $>0.65 \mathrm{ng} / \mathrm{mL}$ (normal: $<0.05 \mathrm{ng} / \mathrm{mL}$ ) suggesting septic process, and lower levels indicative of PFAPA ${ }^{(10)}$ (Fig. 2).

According to the cited paper, PCT indicative of sepsis should justify the implementation of broad-spectrum antibiotic therapy. The case of our patient shows that a value suggesting septic process, unless significantly increased, may also result from an autoinflammatory process, and antibiotic therapy will be unjustified. However, the decision to resign from antimicrobial therapy may be difficult.

Although steroids alleviate the symptoms of PFAPA, they do not prevent further relapses in most patients; therefore, tonsillectomy plays an important role in the management of children diagnosed with PFAPA. The role of tonsils in the disease process is not fully understood. The inflammatory process may arise directly in dysregulated tonsillar cells, or may be initiated locally by mediators from other tissues or a microbial stimulus. In either case removal of the tissue interrupts the inflammatory cascade ${ }^{(11)}$. Surgical treatment leads to permanent remission in $64-100 \%$ of patients ${ }^{(5)}$. Licameli et al. conducted a prospective analysis of long-term outcomes of tonsillectomy. The study included 102 PFAPA patients with 6 months of follow-up after the surgery. Complete resolution of symptoms was observed in 99 patients, while the symptoms persisted in the remaining 3 patients ${ }^{(12)}$. Since tonsillectomy was observed to be associated with postoperative complications, each case should be treated individually, and the procedure should be reserved particularly for patients who do not respond to treatment and children with persistent PFAPA affecting their quality of life. Although PFAPA usually resolves during adolescence, there is growing evidence that this condition may persist into adulthood ${ }^{(13)}$.

\section{CONCLUSIONS}

Although more than 30 years have passed since the first description of PFAPA symptoms, the knowledge on the pathogenesis of this condition is still very limited. Overall clinical assessment and thorough medical history are crucial in the differential diagnosis in children with recurrent febrile 
episodes accompanied by tonsillitis, lymphadenopathy and increased inflammatory markers. Early and correct diagnosis of PFAPA prevents child's exposure to unnecessary antibiotic therapy.

\section{Conflict of interest}

The authors do not report any financial or personal connections with other persons or organisations, which might negatively affect the contents of this publication and/or claim authorship rights to this publication.

\section{References}

1. Haracz J, Tadla M, Fleszar G et al.: Zespół PFAPA u 2-letniej dziewczynki - prezentacja przypadku i przegląd piśmiennictwa. Pediatr Med Rodz 2018; 14: 88-95.

2. Femiano F, Lanza A, Buonaiuto $\mathrm{C}$ et al.: Oral aphthous-like lesions, PFAPA syndrome: a review. J Oral Pathol Med 2008; 37: 319-323.

3. Postępski J, Opoka-Winiarska V, Olesińska E: Zespoły gorączek nawrotowych i cyklicznych. Prz Reumatol 2009; 2 (26): 6-7.

4. Førsvoll J, Øymar K: The role of tonsillectomy in the Periodic Fever, Aphthous stomatitis, Pharyngitis and cervical Adenitis syndrome; a literature review. BMC Ear Nose Throat Disord 2018; $18: 3$.
5. Wolska-Kuśnierz B, Mikołuć B, Motkowski R et al.: Zespół PFAPA - wspólne wyzwanie dla pediatry, immunologa i laryngologa. Stand Med Pediatr 2013; 10: 794-800.

6. Landry A, Docherty P, Ouellette S et al.: Causes and outcomes of markedly elevated C-reactive protein levels. Can Fam Physician 2017; 63: e316-e323.

7. Yazgan H, Keleş E, Yazgan $\mathrm{Z}$ et al.: C-reactive protein and procalcitonin during febril attacks in PFAPA syndrome. Int J Pediatr Otorhinolaryngol 2012; 76: 1145-1147.

8. Førsvoll J, Oymar K: C-reactive protein in the periodic fever, aphthous stomatitis, pharyngitis and cervical adenitis (PFAPA) syndrome. Acta Paediatr 2007; 96: 1670-1673.

9. Brown KL, Wekell P, Osla V et al.: Profile of blood cells and inflammatory mediators in periodic fever, aphthous stomatitis, pharyngitis and adenitis (PFAPA) syndrome. BMC Pediatr 2010; 10: 65.

10. Kraszewska-Głomba B, Szymańska-Toczek Z, Szenborn L: Procalcitonin and C-reactive protein-based decision tree model for distinguishing PFAPA flares from acute infections. Bosn J Basic Med Sci 2016; 16: 157-161.

11. Burton MJ, Pollard AJ, Ramsden JD: Tonsillectomy for periodic fever, aphthous stomatitis, pharyngitis and cervical adenitis syndrome (PFAPA). Cochrane Database Syst Rev 2010; (9): CD008669.

12. Licameli G, Lawton M, Kenna M et al.: Long-term surgical outcomes of adenotonsillectomy for PFAPA syndrome. Arch Otolaryngol Head Neck Surg 2012; 138: 902-906.

13. Vanoni F, Theodoropoulou K, Hofer M: PFAPA syndrome: a review on treatment and outcome. Pediatr Rheumatol Online J 2016; 14: 38 . 